\title{
$\operatorname{Con}-910617$,
}

\section{LOW HEAT REJECTION DIESEL CERAMIC COUPON TESTS}

\author{
CONF-910617--1 \\ C. R. Brinkman, K. C. Liu, R. L. Graves and B. H. West \\ Oak Ridge National Laboratory, Oak Ridge, TN, USA \\ DE91 006274
}

\section{ABSTRACT}

Fesults are reported from studies in which several monolithic ceramic materials in the form of modulus-of.rupture bars were exposed for $100 \mathrm{~h}$ to the combustion conditions found in either a small single- or two-cylinder diesel engine. Fuels included a standard Phillips D-2 diesel or synthetic mixture of the Phillips $D-2$ and an aromatic blend. The ceramics included two commercial grades of partially stabilized zirconia (PSZ-TS and PSZ-MS), silicon nitrio'e (GTE WESGO SNW-1000 and Norton NT-154), and (Hexcloy SA) silicon carnide.

Significant reductions in postexposure four-point bend fracture strenç, th occurred in the PSZ-TS material irrespective of whether it was exposed in the single-or two-cylinder engine. Only a small decrease in fracture strength occurred in the PSZ-MS material, and essentially no decrease in fracture strength occurred in the silicon nitride (GTE WESGO SNW-1000) when tested at room temperature.

The Norton NT-154 silicon nitride was tested at both room temperature and at $700^{\circ} \mathrm{C}$ over several strain rates ranging from $1 \times 10^{-4}$ to $1 \times 10^{-7} \mathrm{~s}^{-1}$. Room temperature tests indicated that the engine exposed bars actually showed a slight increase in average strength, $830 \mathrm{MPa}$, versus $771 \mathrm{MPa}$ for the unexposed material. Elevated temperature strength comparisons showed no reduction in strength due to pre ious engine exposure.

Hexoloy SA silicon carbide showed no reduction in fracture strength when tested at $700^{\circ} \mathrm{C}$.

\section{INTRODUCTION}

Experimental engine exposure of commercially available and developmental ceramic materials in diesel engines began at Oak Ricige National Laboratory (ORNL) in $1985^{1.4{ }^{\circ}}$. The objective of this effort was to determine the effect of diesel engine combustion environment on the structural properties of various structural ceramics by exposing them is conditions found in small diesel engines. Commercially available ceramics, as well as new candidate monolithic and whisker-toughened ceramics, were fabricated into small modulus-of-rupture (MOR) bars into the combustion environment, and then examined destructively and non-destructively.

\section{DISTRIBUTION OF THIS DOCUMENT IS UNLMITED}

* Research sponsored by the U.S. Department of Energy, Assistant Secretary for Conservation and Renewable Energy, Office of Transportation lechnologies as part of the Ceramic Technology for Advanced Heat Engines Project of the Advanced Materials Development Program, under contract DE-AC05-840R21400 with Martin Marietta Energy Systems, Inc.

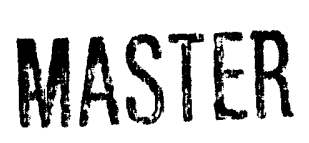




\section{ENGINE TESTING RIG AND SPECIMEN EXPOSURE}

Two small engines were used to expose specimens to combustion conditions. The first was a single-cylinder, air-cooled, indirect-injection diesel (Deutz F1L511W) referred to as engine 1. This engine was a small commercially available driver with a $0.825-L$ \& splacement and a spherical prechamber. The second otherwise identical two-cylinder version of the same engine is referred to as engine 2. Access to the prechamber was made via the unused glow plug port (adjacent to the fuel injector) and a machined port for pressure transducer instrumentation (Fig. 1).

Except for differences in age, these engines were similar. The single-cylinder engine had been used previously for ceramic specimen exposure, whereas the two-cylinder engine was new with new injectors.

Exposure was conducted by "gripping" a pair of MOR bars, that were side-by-side (separated by a thin shim) in a retainer. The retainer was then screwed into the glow plug port, as shown in Fig. 1. Thus, two bars were exposed simultaneously to similar engine operating conditions. Size constraints of the prechamber permitted only 40 to $41 \mathrm{~mm}$ of the bar length to be cantilevered into the chamber. Because of the orientation of the bars direct impingement of the burning fuel spray might have occurred.

Exposure times of $100 \mathrm{~h}$ for each set of specimens were accumulated over several weeks of running several hours daily. Interruptions in exposure also occurred as a result of random corrective maintenance on the engine/dynamometer tandem. The two-cylinder engine was run at a nominal constant speed of 1800 to $1900 \mathrm{rpm}$ and a load of 41 to $43 \mathrm{~N}-\mathrm{m}$ torque. Fuel consumption at these conditions was about $213 \mathrm{~g} / \mathrm{kWh}$, or a fuel energy input of $\sim 21,480 \mathrm{~W}$. The one-cylinder engine was run at similar conditions, with about half the load and fuel consumption of the two-cylinder engine. For either engine, these conditions are $\sim 60 \%$ of rated power output at this speed. Load was absorbed by a small eddy-current dynamometer.

Two fuels were used in this investigation. The first was the reference fuel, Phillips D-2 diesel, and the second was a 5,0/50\% blend of Phillips-D-2 and an aromatic blend. The aromatic blend was $53.5 \mathrm{wt} \%$ Phillips Light Cycle Oil (LCO) and $46.5 \mathrm{wt} \%$ Exxon heavy aromatic naphtha targeted for a lower cetane number and a lower hydrogen content. These blends could simulate fuels derived from coal liquids or heavy oils so the products would have low ignition quality.

\section{TEMPERATURE MEASUREMENT}

An extensive effort was undertaken to determine the in-cylinder temperature profiles of the specimens (2-4). This effort included use of thermocouples, inserted in the centers of drilled PSZ-TS bars placed in the engines, templugs, and fiber optic measurements. Thermocouple measurements in the single cylinder engine revealed bulk internal bar ternjeratures in the range of $700^{\circ} \mathrm{C}$, while in the two cylinder engine values of around $600^{\circ} \mathrm{C}$ were recorded. Templug data indicated that temperatures in excess of $800^{\circ} \mathrm{C}$ occurred in the single cylinder engine. Fiber optic thermometer measurements indicated that transient short term temperatures could reach values of $1100^{\circ} \mathrm{C}$ or higher.

\section{DISCLAIMER}

\footnotetext{
This report was prenared as an account of work sponsored by an agency of the Unitod States Government. Neither the United States Government nor any agency thsreof, nor any of their employees, makes any warranty, express or implied, or assumes any legal liability or responsibility for the accuracy, completeness, or usefulness of any information, apparatus, product, or process disclosed, or represents that its use would not infringe privately owned rights. Reference herein to any specific commercial product, process, or service by trade name, trademark, manufacturer, or otherwise does not necessarily constitute or imply its endorsement, recommendation, or favoring by the United States Government or any agency thereof. The views and opinions of authors expressed herein do not necessarily state or reflect those of the United States Gove:'nment or any agency thereof.
} 


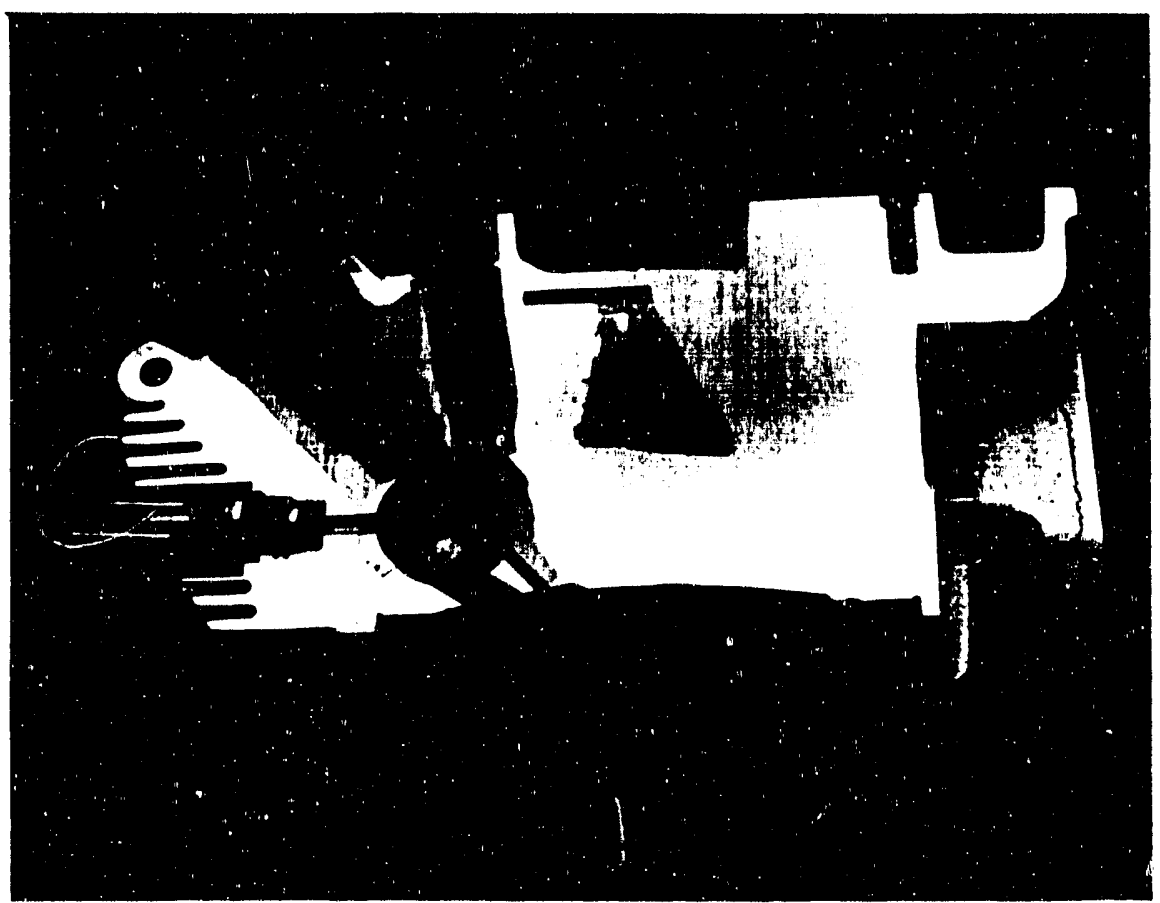

(a) Actual engine head cross section

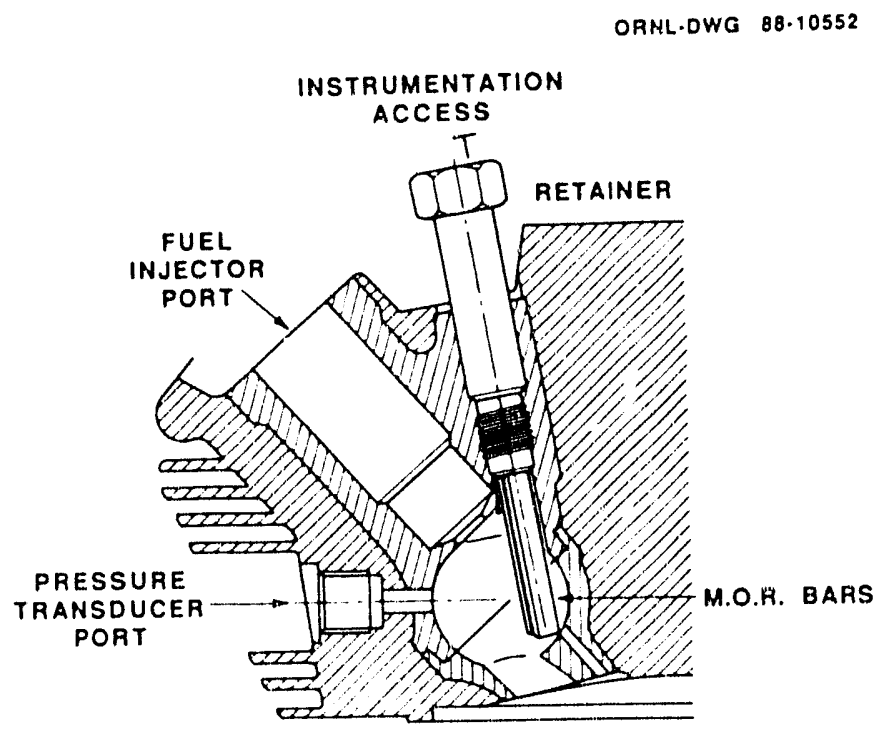

(b) Schematic drawing identifying key features

Fig. 1. Cross sectional view of Deutz cylinder head shows bars' position with respect to fuel injector. 
In summary, currently there is insufficient evidence to conclude that one engirie was hotter than the other because dependable temperature profiles were not available. Cycle-to-cycle variations and sensor installation could easily account for differences recorded to date. Additional work needs to be continued in this area, but it has been shown that in reciprocating engines, this type of material undergoes significant temperature swings and that instantaneous temperatures can be much higher than indicated by passive temperature measurements or conventional thermocouples. For these reasons, postexposure test temperatures for four-point bend flexure tests were selected to be room and $700^{\circ} \mathrm{C}$.

\section{MATERIALS}

Two commercial grades of PSZ, Mg-PSZ-TS (thermal shock resistant) and Mg-PSZ-MS (maximum strength), were obtained from Nilcra Ceramics (USA) in the form of rectangular plates $(101.6 \times 6.35 \mathrm{~mm})$. In the case of PSZ-TS, a second lot (Nilcra Lot 85218 ) was also obtained to determine if there were lot-to-lot variations. This second lot of PSZ-TS is referred to herein as Lot 2, while the previously characterized lot of PSZ.TS (3) is designated as Lot 1.

Two types of commercially available silicon nitride were used in this study, a small block of GTE Wesgo SNW-1000, Lot 174-MA-1607, and a similar block of Norton's NT-154.

A small plate of silicon carbide $(1.6 \times 76 \times 178 \mathrm{~cm})$ designated Hexoloy-SA was obtained from the Carborundum Company.

\section{SPECIMEN PREPARATION AND TESTING}

MOR specimen bars $(50 \times 4.5 \times 3.5 \mathrm{~mm})$ were subsequently cut from the plates or block material. All grinding and polishing of the bars and chamfering of edges were performed in a longitudinal direction to a surface finish of $\sim 0.25 \mu \mathrm{m}$. The PSZ material had an average grain size in the range of 30 to $50 \mu \mathrm{m}$. Unexposed and engine exposed bars were subjected to fourpoint rupture testing in fixtures with an outer span of $40 \mathrm{~mm}$ and an inner span of $20 \mathrm{~mm}$. Figure 2 shows a silicon carbide fixture used for all tests conducted at $700^{\circ} \mathrm{C}$. All rupture tests were conducted in air at a strain rate of $1 \times 10^{-4} \mathrm{~s}^{-1}$ unless specified otherwise.

\section{FLEXURAL STRENGTH RESULTS}

PARTIALLY STABILIZED ZIRCONIA, PSZ-TS (LOT 1) - Figure 3 is a Weibull plot that compares failure probabilities of TS-grade material exposed in engine 2 , which burned synthetic fuel mixture, with similar failure probabilities for unexposed material. Weibull modulus, strengths, and percentage of reduction in strength compared with unexposed material are also given in Table 1. Also tabulated are data previously reported (3) for 14 specimens exposed to engine combustion conditions in both engines 1 and 2 where the reference fuel was employed. Table 1 indicates, from limited data, that the combustion conditions using the synthetic fuel mixture were possibly not as deleterious to the average rupture strength as was the reference fuel.

PARTIALLY STABILIZED ZIRCONIA, PSZ-MS - Figure 4 is a Weibull plot comparing failure probabilities vs strength for the MS-grade material exposed in engine 2 using the synthetic fuel mixtures. A small reduction in strength is apparent. Strength statistics are again compared in Table 1 for this material exposed to engine combustion conditions where the fuel was either the reference or the synthetic fuel mixture. Note that the reduction in strength compared with the unexposed material is about the same regardless of the fuel. 
PARTIALLY STABILIZED ZIRCONIA, PSZ-TS (LOT 2) - Exposure of 18 bars of partially stabilized zirconia, PSZ-TS (Lot 2) was completed in either engines 1 or 2 . The objective of this effort was to determine if specific engine conditions, that is, single vs two-cylinder, made any significant difference in the postexposure strength of a material known to be sensitive to engine environment. The reference fuel was used in both engines. Results of subsequent room temperature four-point bend tests are compared with control specimens in Table 1 and plotted as Weibull curves in Fig. 5.

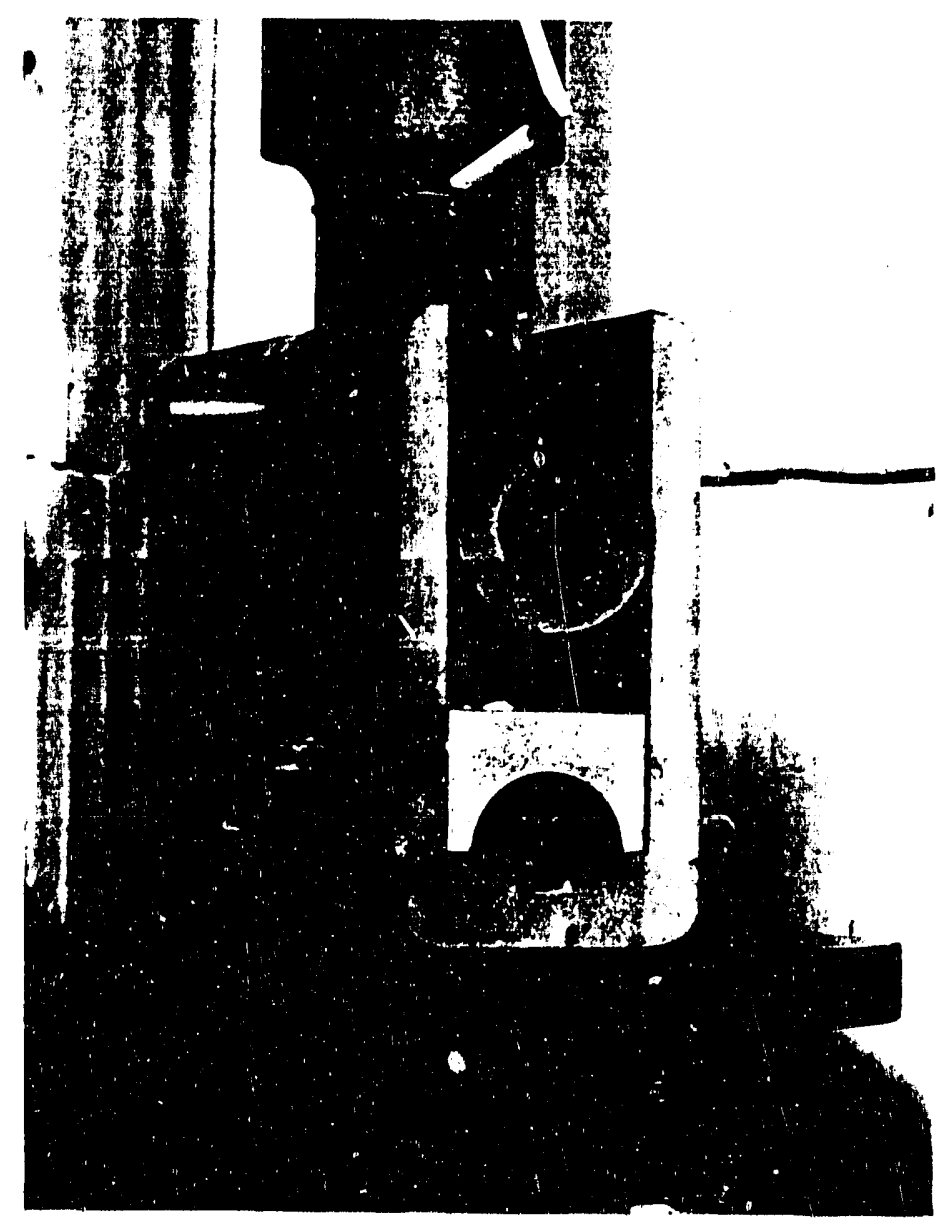

Fig. 2. Silicon carbide four-point bend fixture used for elevated temperature tests. 


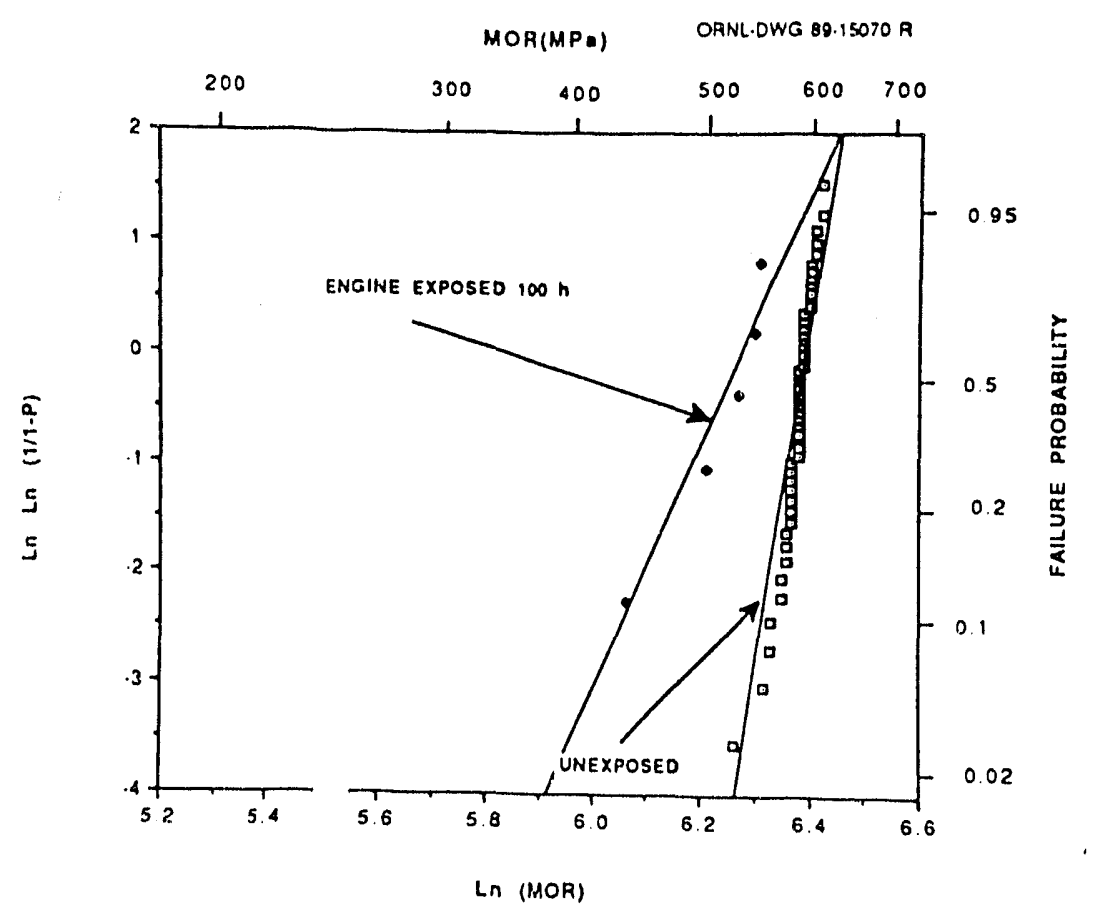

Fig. 3. Weibull plot comparing room temperature fracture strengths of five specimens of Nilcra FSZ-TS grade previously exposed for $100 \mathrm{~h}$ in a diesel engine burning a synfuel mixture with fracture strength of unexposed or control material. 
Table 1. Results of room temperature four-point bend tests" conducted on MOR bars of several different materials

\begin{tabular}{|c|c|c|c|c|}
\hline $\begin{array}{c}\text { Number } \\
\text { of } \\
\text { observations }\end{array}$ & $\begin{array}{l}\text { Material } \\
\text { condition }\end{array}$ & 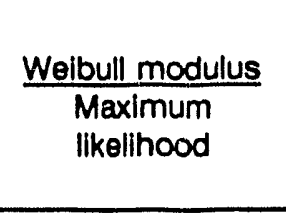 & $\begin{array}{l}\text { Average } \\
\text { strength } \\
\text { (MPa) }\end{array}$ & $\begin{array}{l}\text { Change } \\
\text { in } \\
\text { average } \\
\text { strength } \\
(\%) \\
\end{array}$ \\
\hline \multicolumn{5}{|c|}{ PSZ-TS (Lot 1) } \\
\hline 53 & As fabricated & 48.6 & 587.3 & 0 \\
\hline 5 & $\begin{array}{l}\text { Engine } 2 \text { exposed } \\
\text { for } 100 \mathrm{~h}^{\circ}\end{array}$ & 16.6 & 509.8 & -13 \\
\hline 14 & $\begin{array}{l}\text { Engine } 1 \text { or } 2 \\
\text { exposed for } 100 \mathrm{~h}^{d}\end{array}$ & 4.2 & 401.8 & -32 \\
\hline \multicolumn{5}{|c|}{ PSZ-MS } \\
\hline 40 & As fabricated & 29.7 & 682.9 & 0 \\
\hline 4 & $\begin{array}{l}\text { Engine } 1 \text { exposed } \\
\text { for } 100 \mathrm{~h}^{\mathrm{c}}\end{array}$ & 87.5 & 621.0 & -9 \\
\hline 20 & $\begin{array}{l}\text { Engine } 1 \text { or } 2 \\
\text { exposed for } 100 \mathrm{~h}^{\star}\end{array}$ & 22.0 & 625.0 & -9 \\
\hline \multicolumn{5}{|c|}{ PSZ-TS (Lot 2) } \\
\hline 20 & As fabricated & 25.6 & 629.6 & 0 \\
\hline 6 & $\begin{array}{l}\text { Engine } 1 \text { exposed } \\
\text { for } 100 \mathrm{~h}^{d}\end{array}$ & 5.2 & 413.9 & -34 \\
\hline 12 & $\begin{array}{l}\text { Engine } 2 \text { exposed } \\
\text { for } 100 \mathrm{~h}^{d}\end{array}$ & 6.7 & 444.3 & -29 \\
\hline \multicolumn{5}{|c|}{ GTE WESGO SNW-1000 } \\
\hline 40 & As fabricated & 11.2 & 506.5 & 0 \\
\hline 32 & $\begin{array}{l}\text { Engine } 2 \text { exposed } \\
\text { for } 100 \mathrm{~h}^{\top}\end{array}$ & 14.2 & 512.7 & 1 \\
\hline \multicolumn{5}{|c|}{ NORTON NT-154 } \\
\hline 40 & As fabricated & 11.8 & 771 & 0 \\
\hline 10 & $\begin{array}{l}\text { Engine } 1 \text { exposed } \\
\text { for } 100 \mathrm{~h}\end{array}$ & 12.3 & 825 & 7 \\
\hline 20 & $\begin{array}{c}\text { Engine } 2 \text { exposed } \\
\text { for } 100 \mathrm{~h}\end{array}$ & 15.4 & 828 & 7 \\
\hline
\end{tabular}

\footnotetext{
${ }^{\text {a }}$ Tests were conducted with a cross head speed of $8.47 \times 10^{-3} \mathrm{~mm} / \mathrm{s}$ or a strain rate of $1.1 \times 10^{.4} \mathrm{~s}^{-1}$.
}

${ }^{b}$ Reduction in strength compared with as-fabricated material.

${ }^{\mathrm{C}}$ Fuel was $50 / 50 \%$ blend of Phillips D-2 diesel fuel (reference fuel) and an aromatic blend.

${ }^{d}$ Fuel was control diesel (reference fuel).

${ }^{e}$ Material from Lot 174-MA-1607 and re-heat-treated to sintering temperature. 


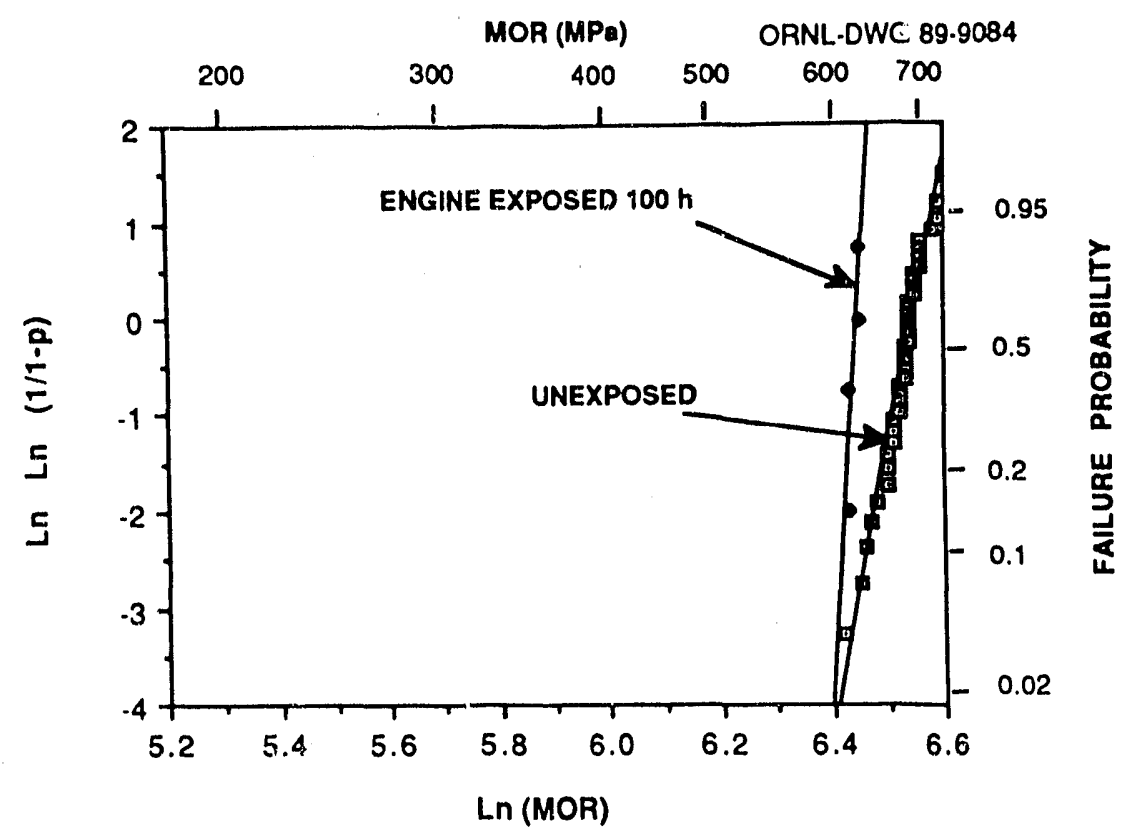

Fig. 4. Weibull plot comparing room temperature fracture strengths of Nilcra PSZ-MS grade, $p$ reviously exposed for $100 \mathrm{~h}$ in a diesel engine burning a synfuel mixture, with fracture strengths of unexposed or control material.

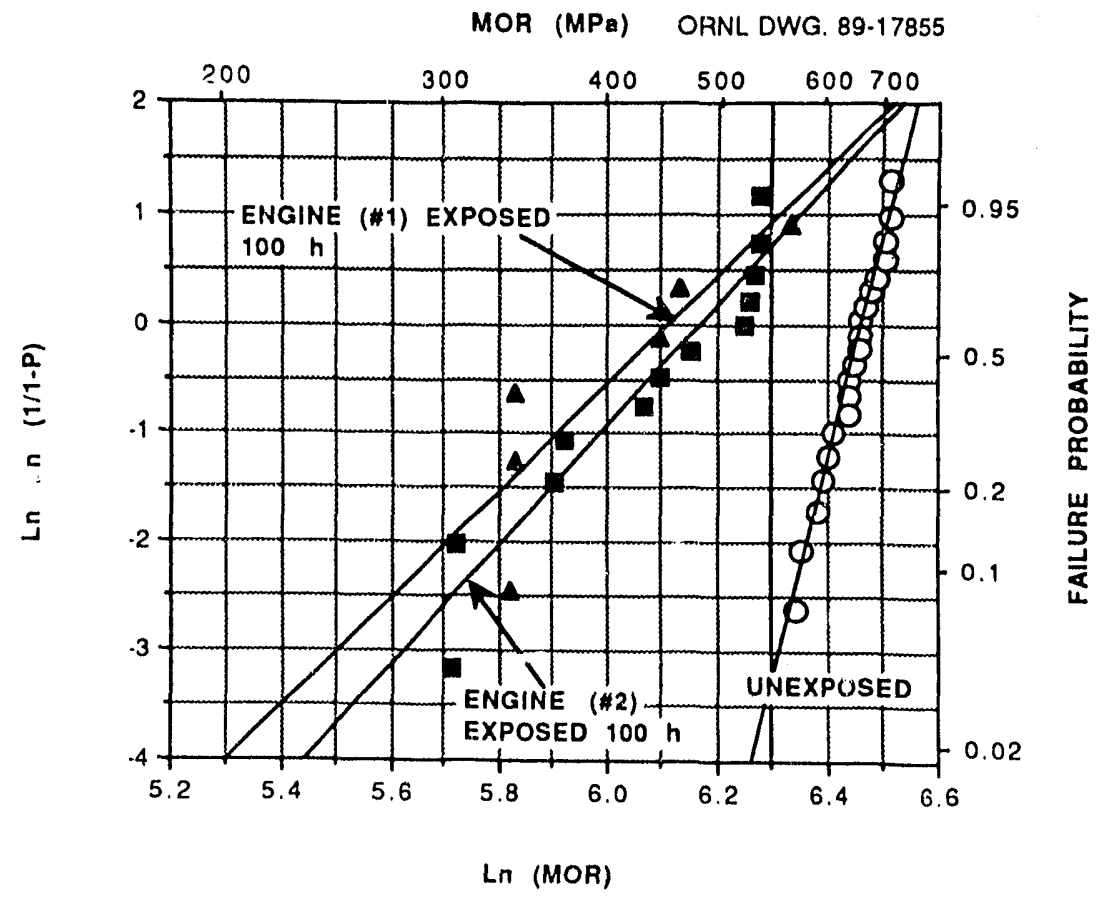

Fig. 5. Weibull plot comparing room temperature fracture strength of Nilcra PSZ-TS grade (Lot 2), previously exposed for $100 \mathrm{~h}$ in a single-cylinder (\#1) and two-cylinder (\#2) diesel engine in a reference diesel fuel combustion environment with similar results from unexposed material. 
Results given in Table 1 indicate a 34 and 29\% reduction in strength after exposure in engines 1 and 2, respectively, compared with as-fabricated or control specimens. Because of the limited data, this difference in strength reduction is not significant. Table 1 also shows that the PSZ-TS (Lot 2) material was slightly stronger than that of PSZ-TS (Lot 1).

SILICON NITRIDE (WESGO SNW-1000) - Using the reference diesel fuel combustion environment, 32 bars were exposed in engine 2. Results aie compared in Table 1 with unexposed or control fracture data. The comparison given in Table 1 shows only a slight (1\%) increase in mean fracture strength compared with the unexposed material, which is not significant and probably within scatter of the data. Figure 6 is a Weibull plot comparison of ihe exposed and unexposed iupture strengths.

This particular lot of material was considerably weaker than expected. The manufacturer was contacted regarding the decreased strength of this lot and reported that this lot had been reheated to the sintering temperature, which may have caused some devitrification.

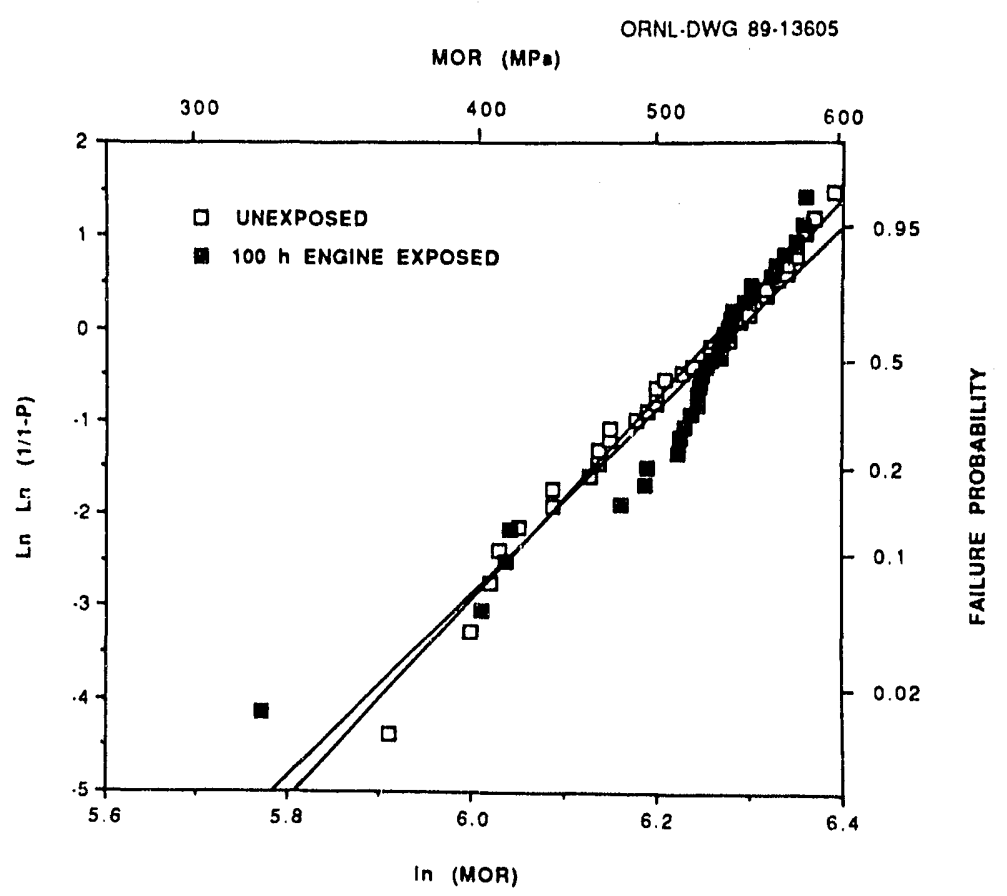

Fig. 6. Weibull plot comparing room temperature fracture strengths of 32 silicon nitride (WESGO SNW-1000) bars exposed for $100 \mathrm{~h}$ in a reference diesel fuel combustion env inment with similar results from unexposed material.

SILICON NITRIDE (NT-154) - A total of thirty bars was exposed for $100 \mathrm{~h}$ in either the single or two cylinder engine and subsequently ruptured at room temperature. Ten of these bars were exposed in the single cylinder engine and the balance was exposed in the two-cylinder engine. Results of these tests are given in Table 1 as Weibull modulus, average fracture strength, and percent change in average strength in comparison to unexposed bar behavior. The data given in Table 1 and shown in a Weibull plot in Fig. 7, indicate that the exposed bars actually showed a slight increase in strength, i.e. about $7 \%$, in comparison to the unexposed bars. 


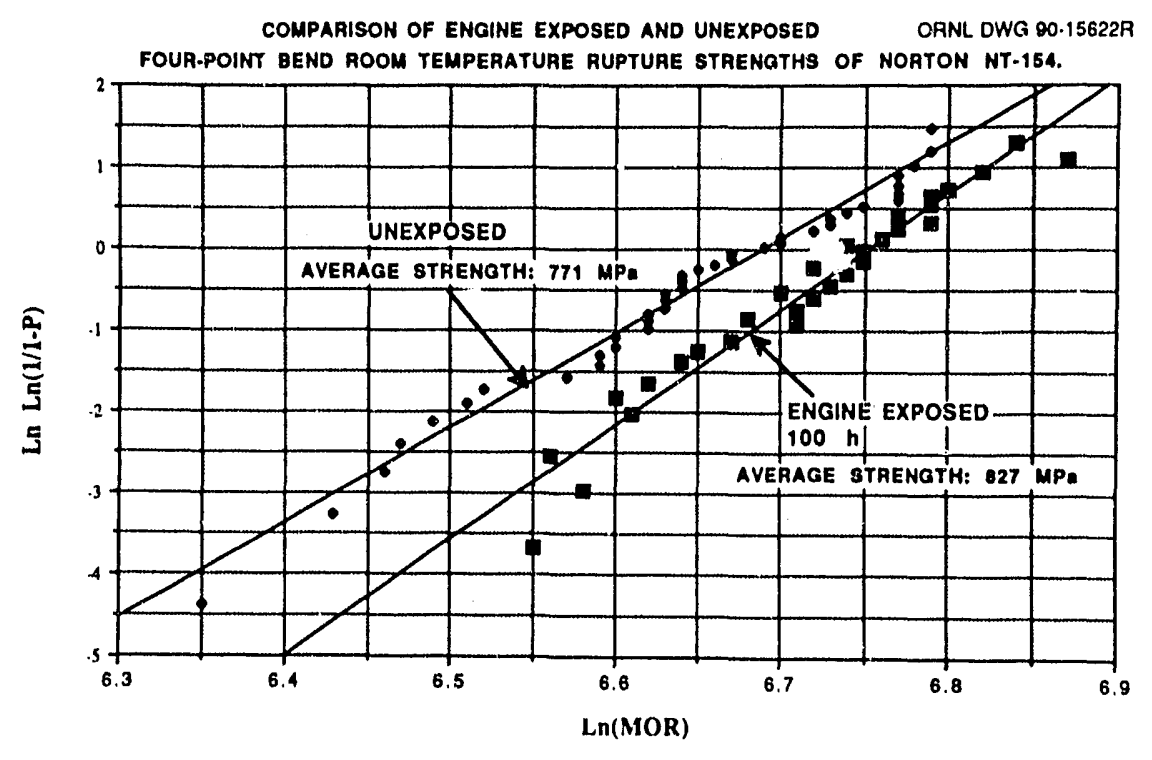

Fig. 7. Comparison of engine exposed and unexposed four-point bend rupture strengths of Norton NT-154.

Figure 8 is a plot of fracture strength as a function of strain rate for NT-154 bars tested in the exposed and unexposed condition. The test temperature was $700^{\circ} \mathrm{C}$ and strain rates rar.ged from $10^{-7}$ to $10^{-4} 1 / \mathrm{s}$. The data indicate no clear trends of either an increase or decrease in fracture strength due to engine exposure.

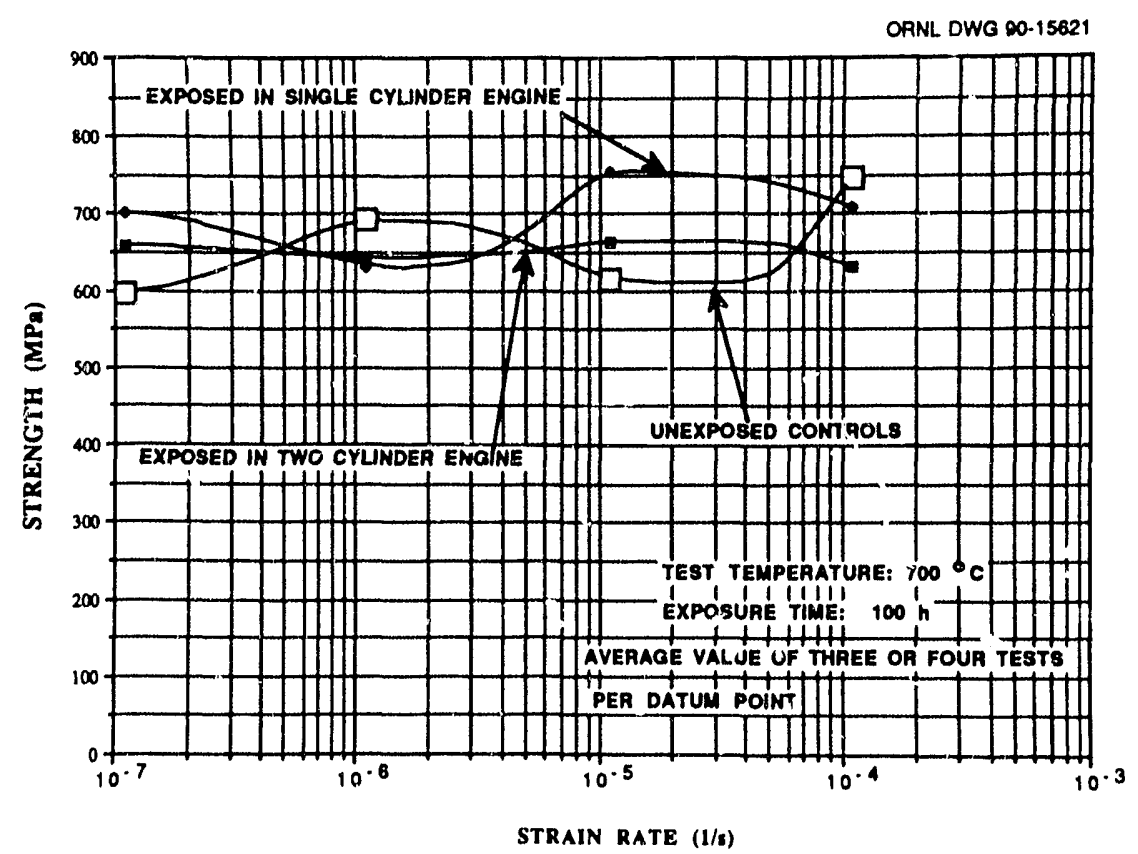

Fig. 8. Fraciure strengths of engine exposed and unexposed Norton NT-154 silicon nitride obtained at several strain rates. 
HEXOLOY SA SILICON CARBIDE - Specimens of silicon carbide were also tested at $700^{\circ} \mathrm{C}$ and at similar strain rates to those used for the NT-154 specimens discussed above. Fig. 9 shows results of the rupture test plotted as rupture strength as a function of strain rate. No effect of engine exposure is apparent from the limited test rasults.

ORNL DWG 90-17604

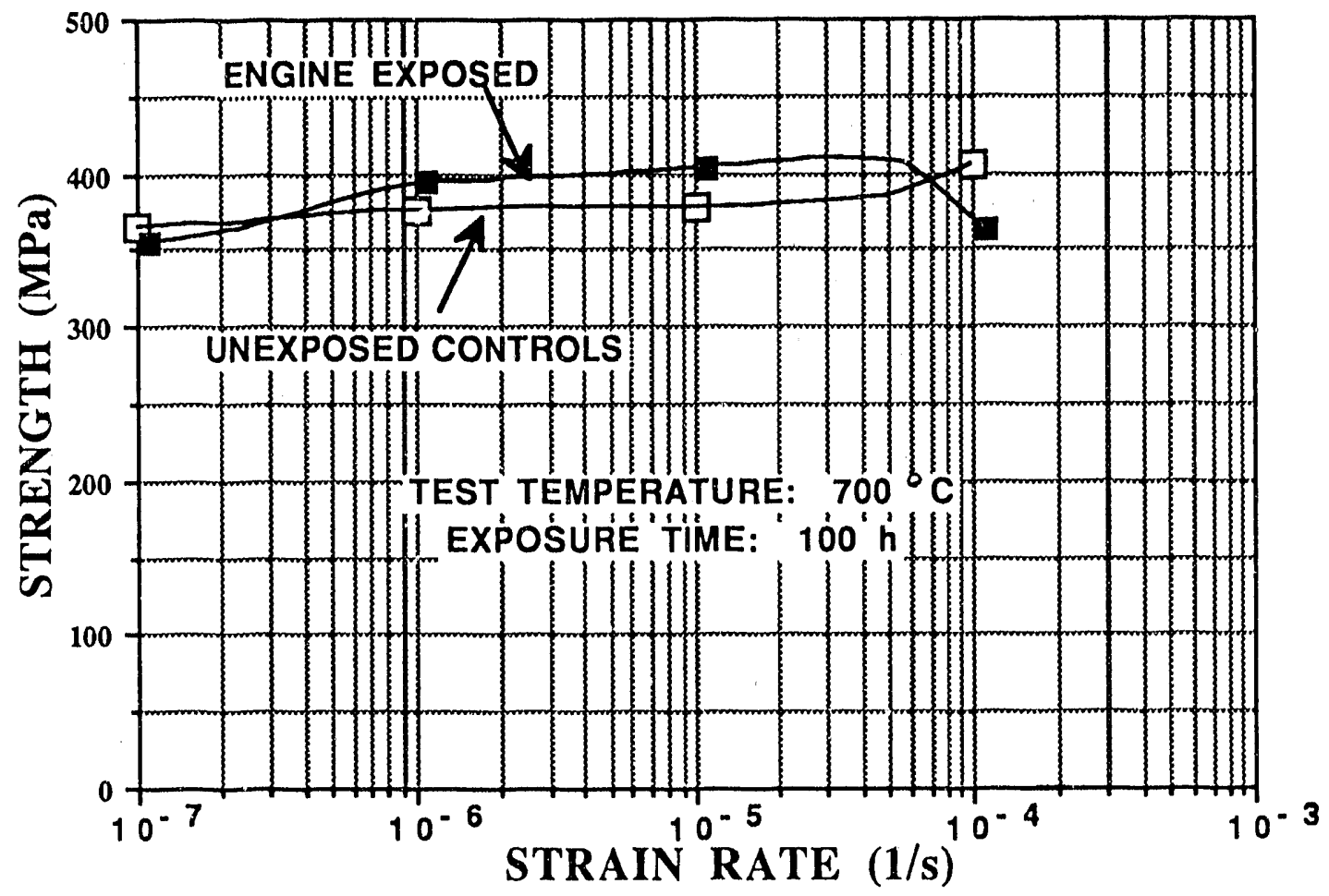

Fig. 9. Fracture strengths of engine exposed and unexposed Hexoloy SA silicon carbide obtained at several strain rates.

\section{VISUAL OBSERVATIONS}

Previous work (3) indicated that in the case of the engine-exposed PSZ-TS grade Lot 1 material, most fractures occurred about 12 to $15 \mathrm{~mm}$ from the cold end for specimens exposed in engine 2 and 33 to $35 \mathrm{~mm}$ from the cold end for specimens exposed in engine 1 . In the case of the PSZ-MS grade, fractures generally occurred at random in the central sections of the bar about 22 to $31 \mathrm{~mm}$ from the cold end. Figure 10 compares the fracture locations of bars exposed in engines 1 and 2. Note that fracture locations of bars inserted in engine 1 tend to be random, but in contrast 9 out of $12(75 \%)$ of the bars exposed in engine 2 failed $\sim 15$ to $20 \mathrm{~mm}$ from the fixed end of the bar, that is, near attachment locations within the engine. These differences suggest somewhat different environments in the two engines. 


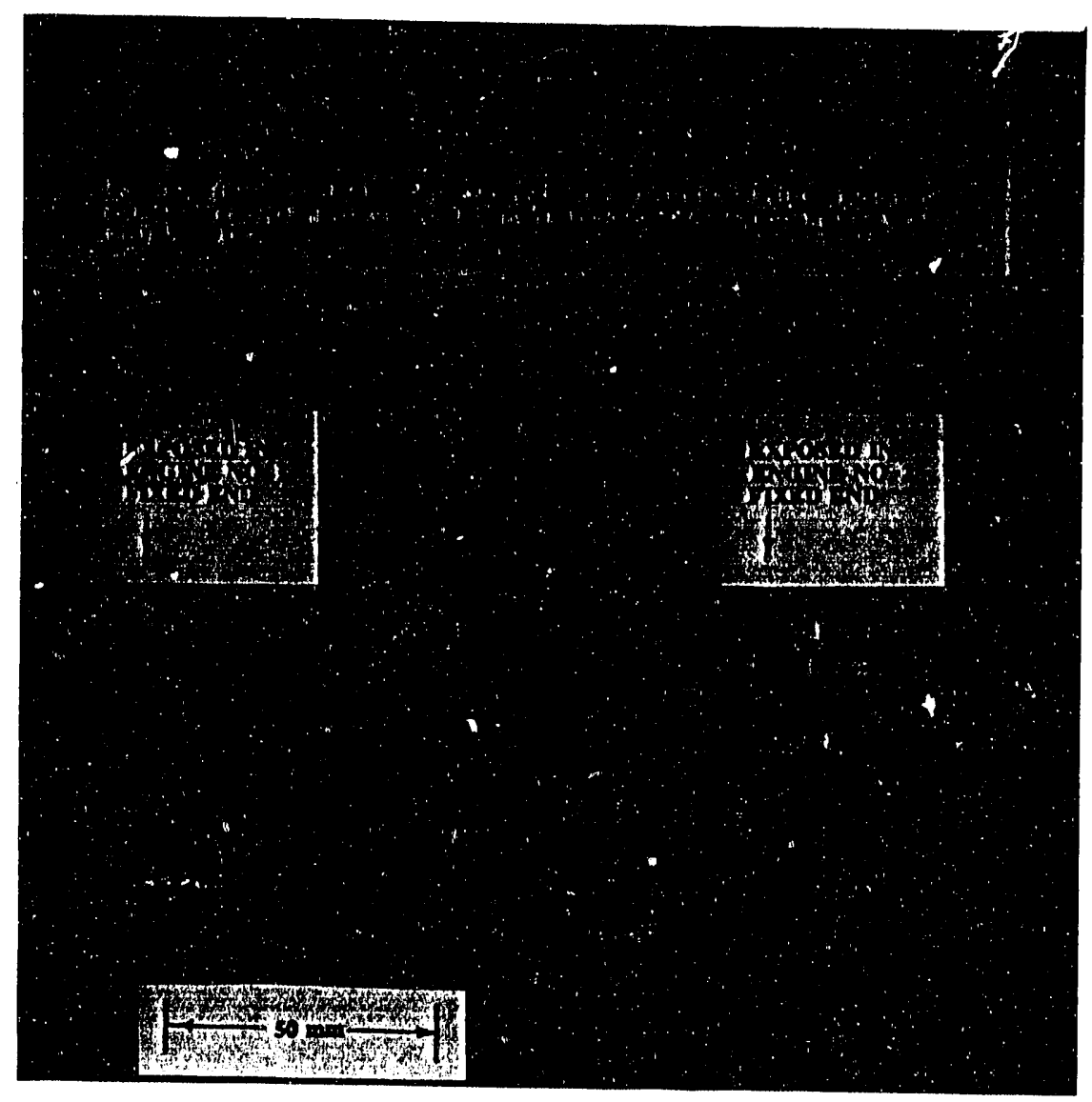

Fig. 10. Comparison of the fracture locations of PSZ-TS bars exposed in two engines. Note preferential four-point bend fracture locations of specimens exposed in engine 2.

Figure 11 shows the four-point bend failure locations of the 32 engine-exposed silicon nitride SNW-1000 specimens. Note the lack of any preferential failure locations in the bars. This observation was also the same for the NT-154 and Hexoloy SA materials. 


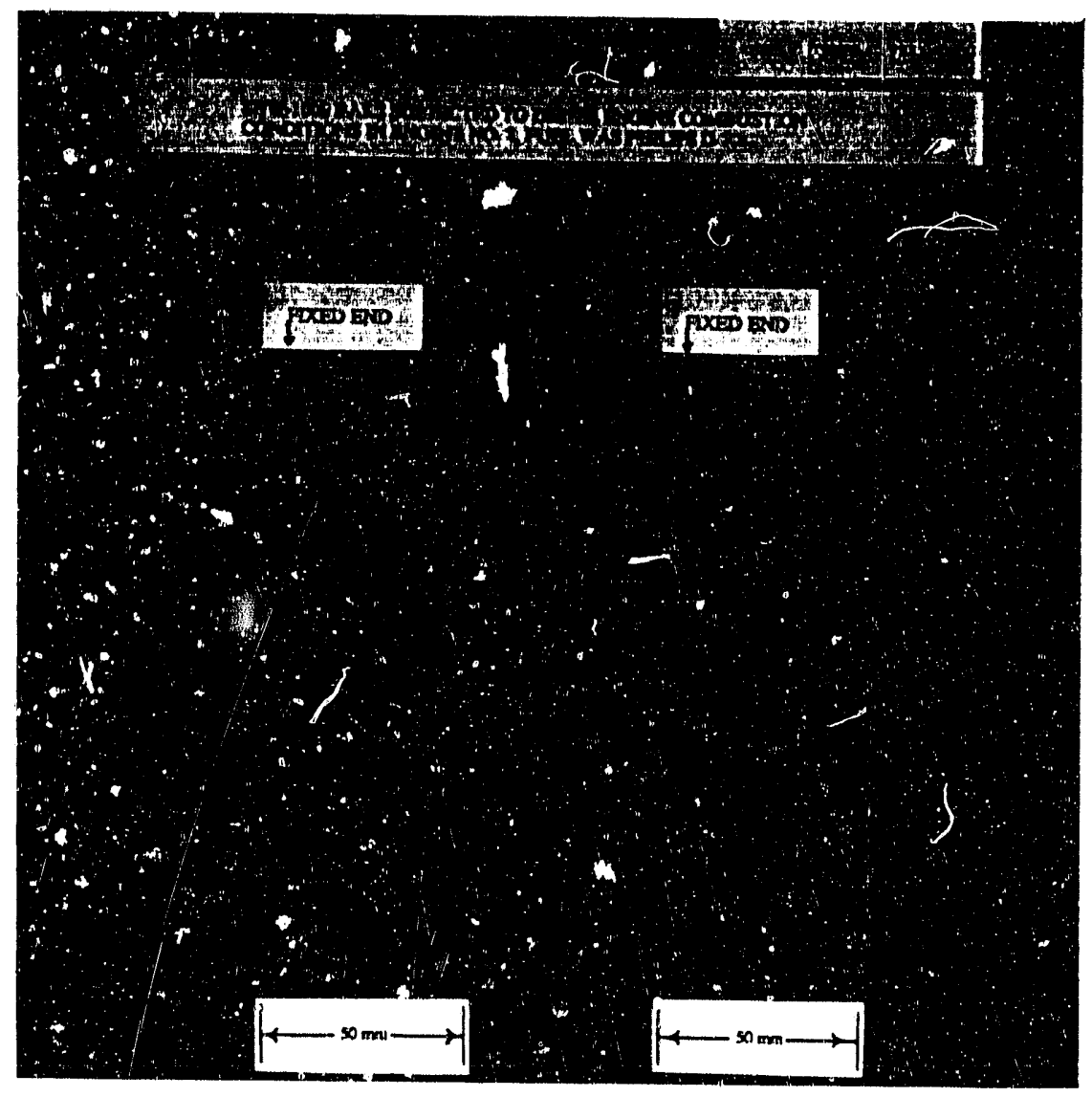

Fig. 11. Failure locations of postexposed specimens of silicon nitride.

\section{RAMAN SPECTROSCOPY EXAMINATIONS}

Raman spectroscopy scans with a laser Raman microprobe were performed on PSZ-TS grade specimens after engine exposure and typical results are shown in Fig. 12. The Raman microp be observations determined the ratio of monoclinic to tetragonal zirconia formed at various points. For convenience in reporting it was assumed that no cubic zirconia was present, and the apparent percentage of monoclinic zirconia was calculated on this basis. Figure 12 silows representative peaks in apparent monoclinic content in the range of 12 to $15 \mathrm{~mm}$ from the cold end of Lot $i$ bars coinciding with subsequent fracture locations. 


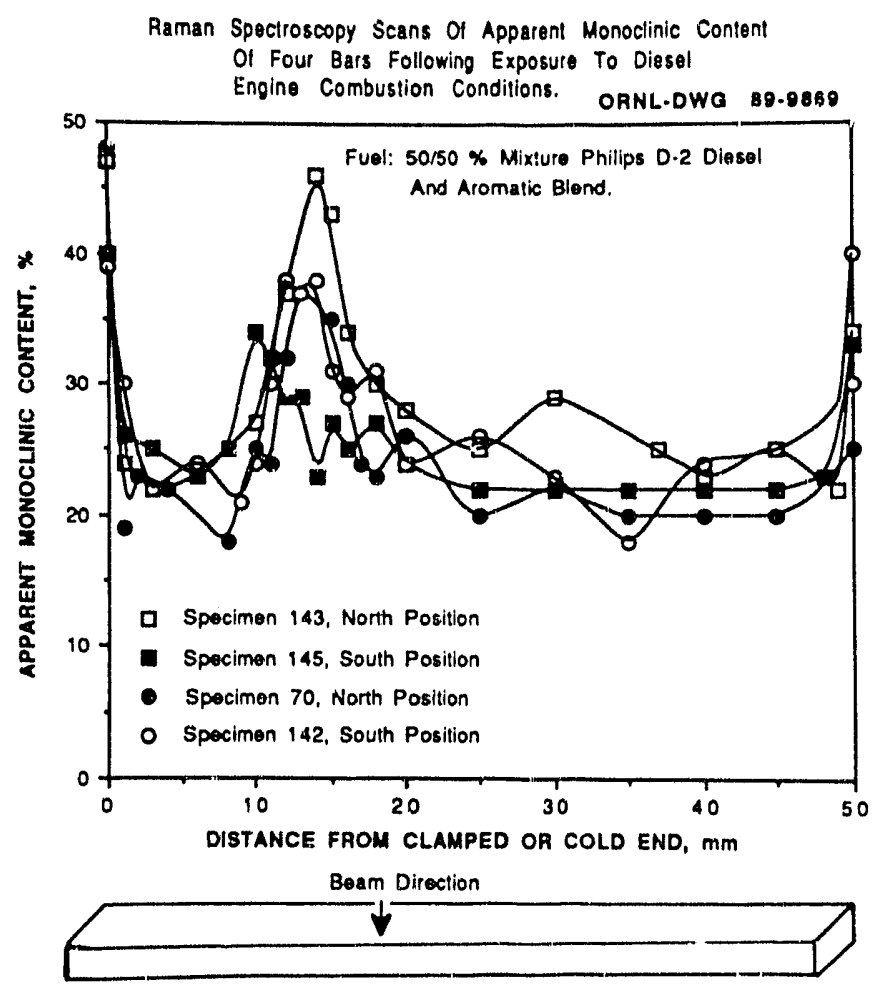

Fig. 12. Raman spectroscopy scans of apparent monoclinic content of four PSZ TS bars following exposure for $100 \mathrm{~h}$ in a diesel engine.

\section{CONCLUSIONS}

Results were reported from rupture studies in which several monolithic ceramic materials in the form of restangular-shaped MOR bars were exposed for $100 \mathrm{~h}$ to the combustion conditions found in iwo diesel engines. The two fuels included in this study were (1) the reference fuel, Phillips D-2 diesel, and (2) a synthetic fuel corlsisting of a mixture of the reference fuel and an aromatic blend. The ceramics included two commercial grades of partially stabilized zirconia, PSZ-TS and PSZ-MS, WESGO SNW-1000 and Norton NT-154, silicon nitride and Hexoloy SA silicon carbide.

1. Heduction in room-temperature four-point fracture strength following exposure occurred in two lots of PSZ-TS material. This reduction occurred irrespective of the fuel employed although there was some indication that the synthetic fuel mixture was slightly less deleterious.

2. Separate sets of specimens of a single lot of PSZ-TS material exp. sed in either a single- or two-cylinder diesel engine that burned the reference fuel showed similar amounts of degradation in fracture strength. 
3. Specimens of PSZ-TS material exposed in the two-cylinder engine that burned the reference fuel showed preferential postexposure failure locations. The points of fracture were in the range oi 15 to $20 \mathrm{~mm}$ from the cold or gripped end of the bais. Raman spectroscopy analysis performed on the postexposed bars before bend testing indicated that the region of failure coincided with a ligh apparent monoclinic phase content induced by engine exposure. A very limited number of specimens exposed in the single-cylinder engine did not show a similar bias in failure location, possibly indicatirig some subtle differences in exposure conditions between the two engines that were prokrably related to injector fouling in the single-cylinder engine. This may suggest that injector integrity is an important parameter to consider when engine components subjected to direct fuel impingement are made of, or coated with, zirconia.

4. Specimens of PSZ-MS showed only a small decrease in postengine exposure fracture strength. This reduction in strength was the same irrespective of the fuel employed, and rio bias was observed in the fracture locations along the bars.

5. Specimens of silicon nitride (WESGO SNW-1000) exposed in the two-cylinder engine that burned the reference fuel showed essentially no degradation ir postexposure fracture strength. No bias in fracture locations was noted in the bars following four-point bend fracture testing.

6. Spesimens of silicon nitride (Norton NT-154) exposed in either the single- or twocylinder engine showed a slight increase $(7 \%)$ in room temperature fracture strength in comparison to unexposed material. No effect of strain rate or exposure condition was found on the fracture strength of bars tested at $700^{\circ} \mathrm{C}$.

7. Specimens of silicon carbide (Hexoloy SA) showed no effect of exposure condition or strain rate on the fracture strength when tested at $700^{\circ} \mathrm{C}$.

\section{REFERENCES}

1. R. L. Graves, W. K. Kahl, and E. L. Long, Jr., Testing of Developmental Materials in Diesel Ergine Combustion Chambers, Paper 87-ICE-28, The American Society of Mechanical Engineers, New York, Energy Sources Technology Conference and exhibition, Dallas, Texas, February 15-20, 1987.

2. C. R. Brinkman et al., Influence of Diesel Engine Combustion on the Rupture Strength of Partially Stabilized Zirconia, ORNL-6153, Martin Marietta Energy Systems, Inc., Oak Ridge National Laboratory, December 1988.

3. C. R. Brinkman et al., Influence of Diesel Engine Combustion on the Rupture Strength of Partially Stabilized Zirconia, Ceramic Bulletin, The American Cerarnic Society Inc., Vol. 68, No. 8, August 1989, pp. 1440-45.

4. C. R. Brinkman et al., Influence of Diesel Engine Exposure on the Rupture Strength of Silicon Nitride and Partially Stabilized Zirconia, ORNL-6612, Martin Marietta Energy Systems, Inc., Oak Ridge National Laboratory, June 1990. 

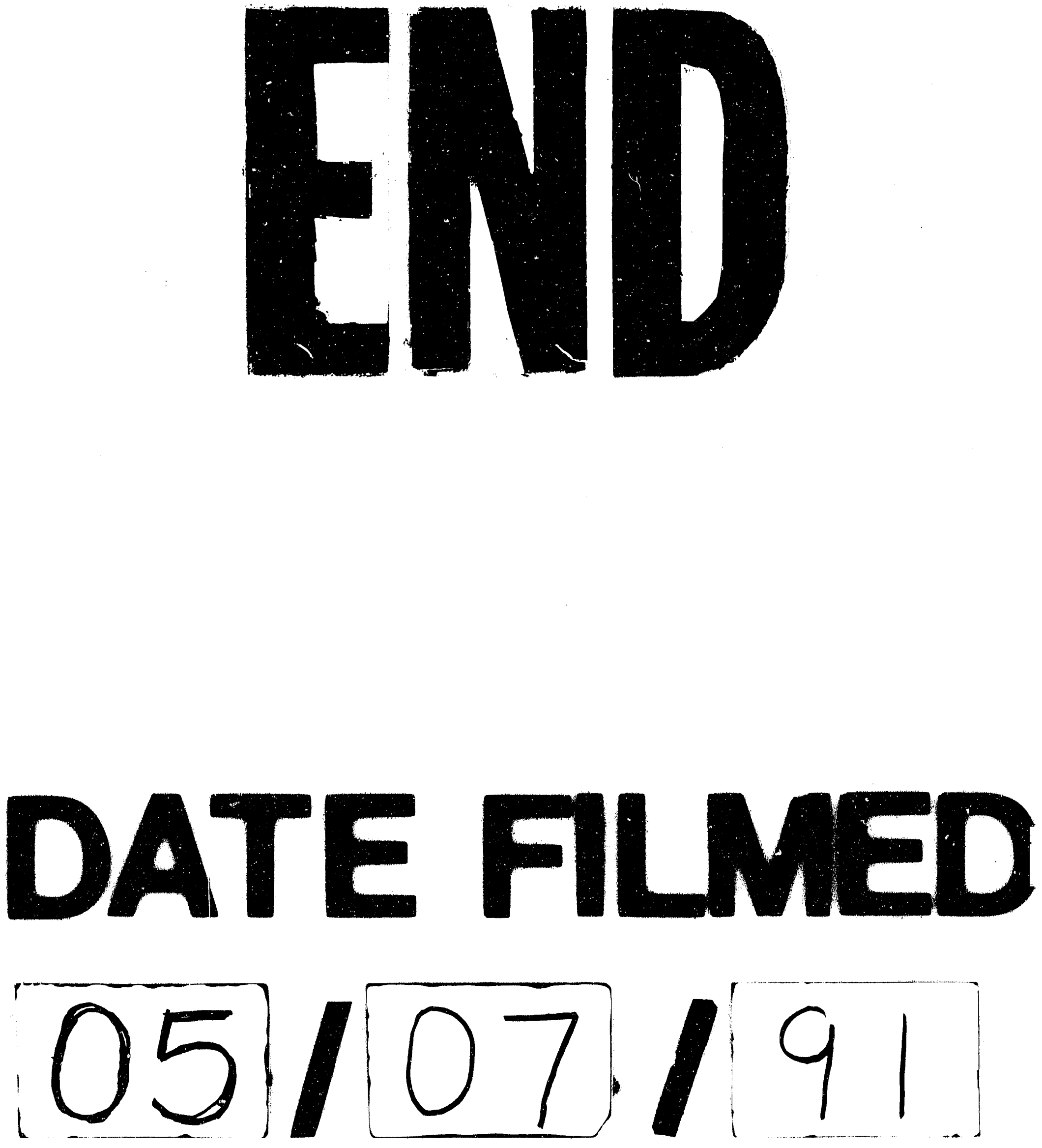
